"Mircea cel Batran" Naval Academy Scientific Bulletin, Volume XIX - 2016 - Issue 1

Published by "Mircea cel Batran" Naval Academy Press, Constanta, Romania /I The journal is indexed in:

PROQUEST / DOAJ / DRJI / JOURNAL INDEX / I2OR / SCIENCE LIBRARY INDEX / Google Scholar / Crossref /

Academic Keys / ROAD Open Access / OAJI / Academic Resources / Scientific Indexing Services / SCIPIO

\title{
IMPLEMENTATION PHOTOVOLTAIC PANELS IN LIGHTING SYSTEM OF A SHIP
}

\author{
Florenţiu DELIU1 \\ Petrică POPOV 2 \\ Paul BURLACU ${ }^{3}$ \\ Vasile DOBREF ${ }^{4}$ \\ ${ }^{1}$ Lecturer PhD eng.Naval Academy “Mircea cel Batran”, Constanța, florentiu.deliu@anmb.ro \\ ${ }^{2}$ Lecturer PhD Naval Academy "Mircea cel Batran", Constanța, petrica.popov@anmb.ro \\ ${ }^{3}$ Lecturer PhD eng.Naval Academy “Mircea cel Batran”, Constanța, paul.burlacu@anmb.ro \\ ${ }^{4}$ Professor PhD eng. Naval Academy “Mircea cel Batran”, Constanța, vasile.dobref@anmb.ro.
}

Abstract: The possibility of using other sources of electricity than conventional one, on board vessels, is a highly actual subject. In this respect, this paper presents a simulation on the development of a proper photovoltaic panels configuration used for the lighting system of the ship, with $42 \mathrm{~kW}$ installed average power.

Keywords: photovoltaic panels; lighting system

1. Introduction.

The emission of greenhouse gases pose a serious threat in terms of producing climate change, with potentially disastrous effects on mankind. The use of renewable energy sources (RES), along with improving the efficiency of energy (EE), can help to reduce energy use, reduce emissions of greenhouse gases and, consequently, to prevent dangerous climate change.

The mechanisms by which it changes the intensity of the solar radiation at the crossing of the atmosphere, are absorption and diffusion. In the atmosphere is absorbed (retained, filtered) almost all the radiation $X$ and part of the ultraviolet radiation. Water vapor, carbon dioxide and other gases existing in the atmosphere, contributes to the absorption of solar radiation by the atmosphere. The absorbed radiation is generally converted into heat, and radiation diffused thus obtained is returned in all directions. Through these processes, the atmosphere heats up and in return produces a radiation with high wavelength , called atmospheric radiation. In addition to the two mechanisms of change in the intensity of solar radiation, part of the solar radiation is reflected by the terrestrial atmosphere, or some of its components (air molecules and certain categories of clouds). Through reflection, part of the solar radiation is dissipated, the mechanism of this process being called Rayleigh diffusion, and this phenomenon represents the heavenly vault and radiation.

Global radiation coming from the Sun, on a horizontal surface at ground level in a clear, windless day is the sum of direct radiation and diffuse radiation. Direct solar radiation depends on the orientation of the receiving surface. Diffuse solar radiation can be considered the same, regardless of the orientation of the surface, even though in reality there are slight differences.

Uniform heat energy received from the Sun, measured at the level of the Earth's surface, perpendicular to the direction of sunlight, for the conditions in which the sky is perfectly clear and devoid of pollution in areas of Western Europe, Central Europe and Eastern Europe, around noon, may provide a maximum of $1000 \mathrm{~W} / \mathrm{m} 2$. This value is the sum of direct and diffuse radiation. Solar radiation is influenced by the permanent modification of several important parameters, such as the height of the Sun in the sky (the angle formed by the direction of the Sun's rays with the horizontal plane), the angle of inclination of the Earth axis, changing Earth-Sun distance (about 149 million km elliptical trajectory, slightly eccentric), geographical latitude.

In Figure 1 is represented the variation of density of solar radiation depending on the height of the Sun, meaning the angle between the direction of sunlight with the horizontal plane, for different atmospheric situations.

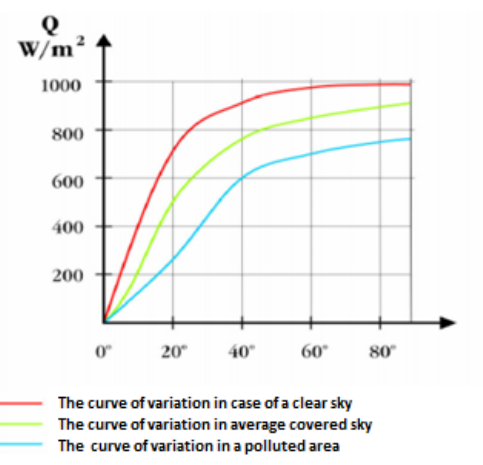

2. Solar radiation 
"Mircea cel Batran" Naval Academy Scientific Bulletin, Volume XIX - 2016 - Issue 1

Published by "Mircea cel Batran" Naval Academy Press, Constanta, Romania // The journal is indexed in: PROQUEST / DOAJ / DRJI / JOURNAL INDEX / I2OR / SCIENCE LIBRARY INDEX / Google Scholar / Crossref /

Academic Keys / ROAD Open Access / OAJI / Academic Resources / Scientific Indexing Services / SCIPIO

Due to its passage through the atmosphere, solar radiation is subject to phenomena of absorption, diffusion and transmission being reduced by about $30 \%$. At ground level, solar radiation can classify into:

- direct radiation-parallel component of the solar disk and measured after the direction of the normal to the surface.

- diffuse radiation-radiation received by a flat surface originating from the whole hemisphere seen on that surface, with the exception of the solar disk.

- the reflected radiation is the result of reflection by the reflective surfaces; This component is dependent on the albedoul surface in question.

- global radiation-direct radiation and diffuse radiation.

For the operation of the PV panels, direct radiation is most important. In the case of clear skies, it has the highest intensity when the Sun is at its maximum towards the South in the northern hemisphere, and North in the southern hemisphere. This is due to the short distances that electromagnetic waves must travel along Earth's atmosphere. The inclination of a Southfacing surfaces, as shown in Figure 2, and her position towards the Sun is described by the angle $\mathrm{h}$ (height from the Sun at that time) and the azimuth angle. Due to the movement of the Earth's revolution, the position of the Sun is different from the area in Figure 2 and depending on the season.

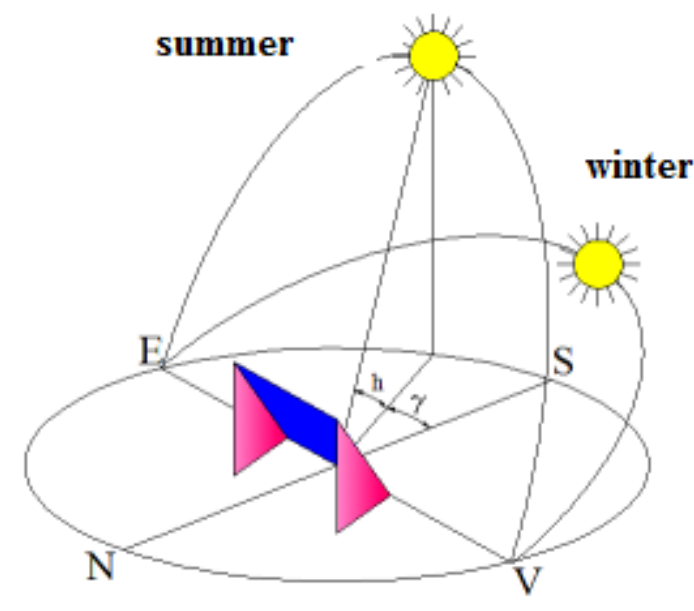

Figure 2. Solar angles

At the same time, the intensity of the solar radiation depends on the zenith angle and atmospheric state, including content of ozone, water vapor, aerosols, dust and clouds.

\section{Modeling the operation of photovoltaic panels}

In the literature there are several ways of describing how a photovoltaic cell works. Because they are generating a photocurrent, the most common patterns are obtained by the superimposition of the feature of a semiconductor diode with a power generator, voltageindependent. To these are added the losses through electrical resistances of the material itself, the electrical contacts and other phenomena that take place inside the photovoltaic cell [EIC 03].

Maximum power point. Electric power delivered by a photovoltaic cell is not sufficient for the majority of domestic or industrial applications. For this reason, photovoltaic cells are formed in series to increase the voltage to the terminals and this is how a Panel (module) is created. Then, you can assign modules either in series for a higher voltage, either in parallel to increase the current through the circuit. These series-parallel associations form photovoltaic fields.

Voltage-current characteristic (U-I) of a photovoltaic module depends primarily on the intensity of solar radiation and temperature of cells. So for different meteorological parameters there is a characteristic of the operation of the photovoltaic generator. At the intersection of $\mathrm{U}-\mathrm{I}$ characteristic with the electrical charge feature of $\mathrm{PV}$ generator terminals is found operating point (FP). Overall, this point is different from the maximum power point (MPP), at which the system can function, when the optimum power transfer can be achieved between generator and load.

Accordingly, MPP depends on the operating conditions of the photovoltaic generator, and electrical characteristics of the electrical charge from the terminals. The purpose of the tracking systems of the maximum power point (MPPT) is to maintain the operating point as close as possible to the MPP.

To achieve maximum power transfer between the $\mathrm{PV}$ generator and receiver a DC-DC converter is attached.

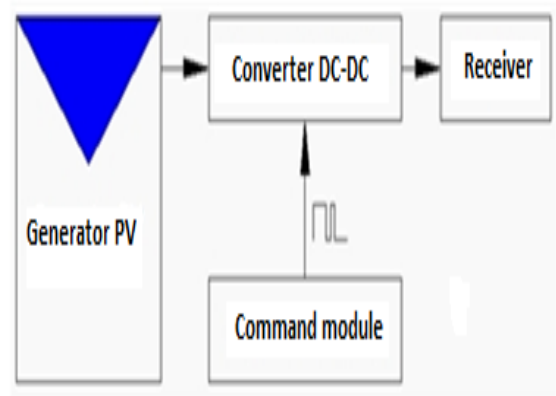

Figure 3 User adaptation of resistive load 
"Mircea cel Batran" Naval Academy Scientific Bulletin, Volume XIX - 2016 - Issue 1

Published by "Mircea cel Batran" Naval Academy Press, Constanta, Romania // The journal is indexed in: PROQUEST / DOAJ / DRJI / JOURNAL INDEX / I2OR / SCIENCE LIBRARY INDEX / Google Scholar / Crossref /

Academic Keys / ROAD Open Access / OAJI / Academic Resources / Scientific Indexing Services / SCIPIO

Acquisition systems for photovoltaic panels. A data acquisition system (SAD) is intended to retrieve information of a physico-chemical system in a usable form. This information is chemical or physical parameters of the system studied, whose size should be provided.

In an automatic complex system, SAD takes the chemical or physical parameters of the process and sends them towards the display block or the stocking, processing and command block. Depending on the results of the processing, the command shall be transmitted to the command element, which will modify the operating parameters of the process. The General layout of such a system is shown in Figure 4.

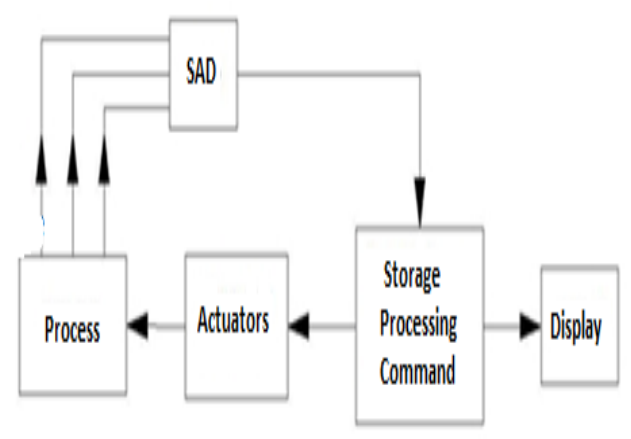

Figure 4: SAD block diagram

Sensors and conditioning circuits. In general, signal processing by the specialized circuitry and devices can be made if these are in the form of voltage. Thus, conditioning circuits convert electrical signals from the sensors when they are not in the form of voltage. If the electrical signals have variations, then the conversion is done in a voltage with an amplitude and frequency determined at the exit sensor. In addition, some circuits of conditioning offer the possibility to correct the signal, such as compensating the undesirable effects through amplification, filtering and linearising.

Thermocouple conditioning. Because they are cheap, resistant and can operate on a wide range, thermocouples are temperature sensors used in photovoltaic systems. Their operation is based on the Seebeck effect-generating a thermoelectromotive voltage variable with the temperature at the terminals of a junction of two different metals. Their conditioning supposes the existence of a voltage value of reference applied to one of the connection points of the cold end. This operation is called compensation and can either be done hardware with a identical polarized inverted junction and maintained at a constant temperature, either software, knowing the ambient temperature.

4. Simulation of the photovoltaic system on the ship with Homer.

Simulation aimed the implementation of photovoltaic panels in the lighting system, the average power consumed being approximately 42 kw per hour. This approximates that the energy consumption belongs to the lighting system.

Photovoltaic panels have the following characteristics:

-hexagonal shape of $0.233 \mathrm{~m}$ radius;

-efficiency $15 \%$;

-power for 400 panels $=337 \mathrm{kw}=>14 \mathrm{kw} / \mathrm{h}$;

-Special features:-pressure resistant, withstanding up to 110 t weights;

-shock-resistant;

-automatic heating system, are not affected by water or snow;

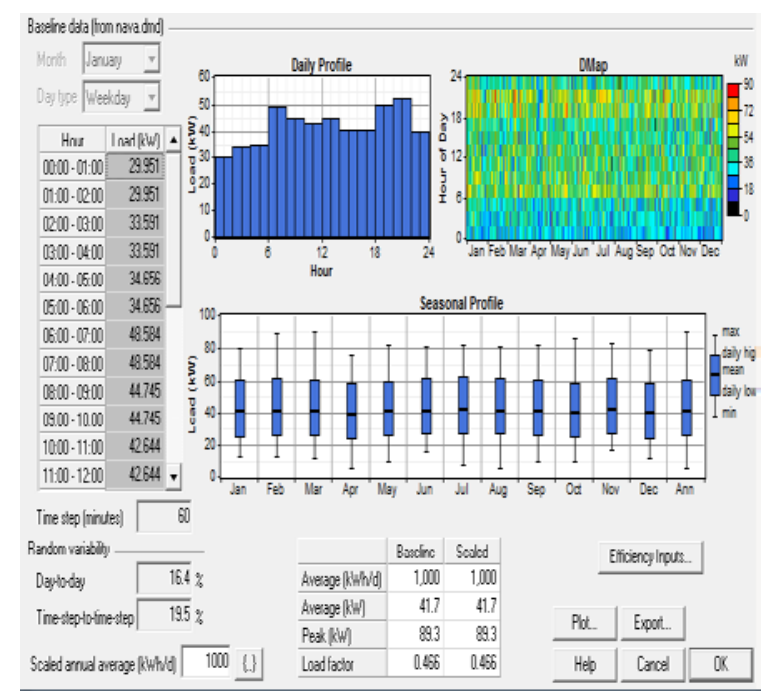

Figure 5

In parallel with photovoltaic panels, the power supply shall be taken into account one of diesel generators of $259 \mathrm{kw}$. Theoretical results are traditionally given in a time span of 25 years and focus on observing the toxic emissions, fuel economy and the recovery of the investment. 
"Mircea cel Batran" Naval Academy Scientific Bulletin, Volume XIX - 2016 - Issue 1

Published by "Mircea cel Batran" Naval Academy Press, Constanta, Romania // The journal is indexed in: PROQUEST / DOAJ / DRJI / JOURNAL INDEX / I2OR / SCIENCE LIBRARY INDEX / Google Scholar / Crossref / Academic Keys / ROAD Open Access / OAJI / Academic Resources / Scientific Indexing Services / SCIPIO

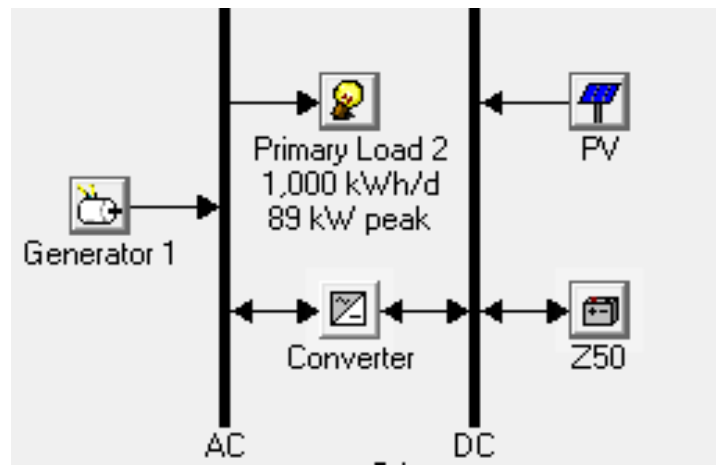

Figure 6 Principle and scheme resources

$\mathrm{PV}=$ photovoltaic panels

- $14 \mathrm{kw} /$ day, placed horizontally, the life span of 30 years, $15 \%$ efficiency

$\mathrm{Z} 50$ = batteries products ZBB energy corporation

- Provides $50 \mathrm{~kW}$, maximum charging rate $17 \mathrm{kw}$, maximum discharge rate $25 \mathrm{kw}$;

- High cycle of life, up to 1000 discharges;

- Without loss in performance due to repeated discharges.

Converter = energy converter

Generator = one of the ships DG's

Primary load $=$ consumers

$A C=$ alternating current

$\mathrm{DC}=$ direct current
Establishing solar power factor and functional parameters (fig. 7)

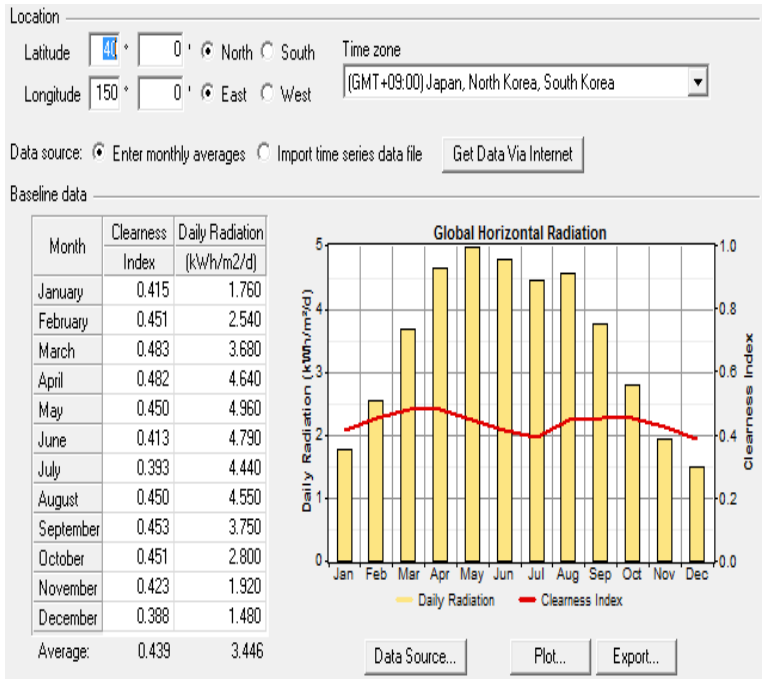

Figure 7

The data belong to the West coast of Japan, over a year ago, with an annual average of 3.4 $\mathrm{kW} / \mathrm{m}^{2} /$ day

\section{CONCLUSIONS}

On the basis of the analysis made on ship, taking into account variables such as the amount of solar energy and fuel price but also technical data such as those of the vessel and the characteristics of photovoltaic panels, the simulation system of calculation of Homer led to the appearance of the following conclusions:

- Implementation of photovoltaic panels enhances the life of the generator up to 80 years ( with no panels, at the same operating procedure, generator has a life span of 20 years);

- The investment pays off in 20 years.

- Reduce fuel consumption and emissions of carbon dioxide, bringing the amount of $678,792 \mathrm{~kg} / \mathrm{year}$ of $\mathrm{CO} 2$ emission to $247,827 \mathrm{~kg} / \mathrm{year}$;

- Cost per kw produced by photovoltaic panels is $0.01 \$$ cheaper than that produced by the generator;

\section{BIBLIOGRAPHY}

[1] Andreescu D. Estimated in control systems of electrical drives, Ed Politehnica Timişoara.

[2] Babescu M., Păunescu D., Electrical Machines - mathematical analysis of the transitional arrangements,

Ed. Polithenica, Timişoara, 2001

[3] Boldea I., Nasar S.A., Vector Control of AC Drives, CRC Press, Florida, 1992

[4] Jiao S.,Hunter G.,Ramsden V., Patterson D.,Control system design for a $20 \mathrm{KW}$ wind turbine generator with a boost converter and battery bank load, in Proc. IEEE PESC, Vancouver, BC, Canada, Jun. 2001, pp. 2203-2206

[5] Kana C. L.,Thamodharan M., Wolf A.System management of a wind energy converter, IEEE Trans. Power Electron., vol. 16, no. 3, pp. 375-381, May 2001

[6] Karlsson P.,DC distributed power systems-Analysis, design and control for a renewable energy system, Ph. D. dissertation, Lund Univ., Lund, Sweden,2002

[7] Lane N.,Boesch D. F.-Vision 2033, part 6: Energy, the environment, and global change. The American Association of the Advancement of Science [Online].2004

[8] Park. J.K Control of state-constrained linear dynamical systems: Antireset windup approach, IEEE Proc. Control Theory Appl. Vol.147, No.2 February 2000 